\title{
Mødrenes hivinfeksjon påvirker tarmbakteriene hos barna
}

\author{
Kan høyere sykelighet og dødelig- \\ het hos friske barn født av mødre \\ med hivinfeksjon forklares med \\ endret sammensetning av tarm- \\ bakteriene?
}

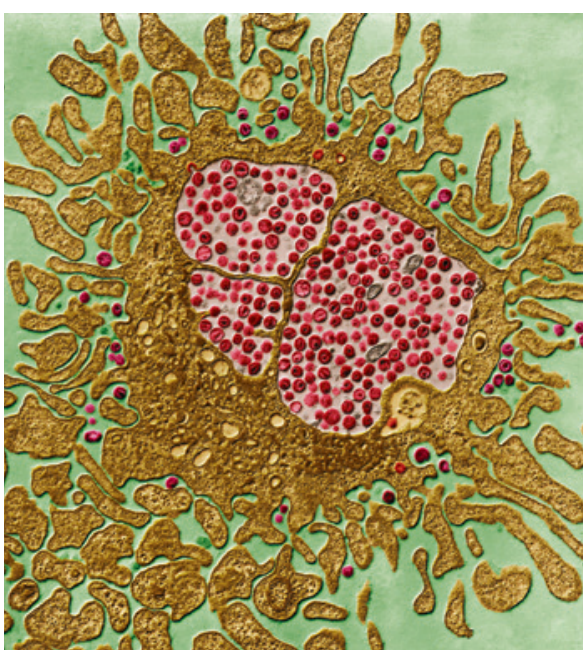

Farget transmisjonselektronmikroskopi viser røde hivpartikler på overflaten av en hvit blodcelle. Foto:

Science Photo Library
Hos 50 mødre med barn i byen Port-auPrince på Haiti, like mange hivpositive som hivnegative, ble bakteriesammensetningen $\mathrm{i}$ tarmen undersøkt (1). Sekvensering av variabel region på ribosomale bakteriegener ble brukt for å karakterisere bakteriemangfoldet. Det viste seg at bakteriesammensetningen i spedbarnets avføring var avhengig av morens hivstatus. Friske barn født av mødre med hivinfeksjon hadde lavere bakteriemangfold enn friske barn født av mødre uten hivinfeksjon.

Melkesukkersammensetningen i brystmelken ble undersøkt med væskekromatografi. Der fant man forskjeller mellom de to mødregruppene som kan forklare endringene i bakteriesammensetningen. Denne endringen i tarmflora, assosiert med morens hivstatus, kan være en del av årsaken til økt sykelighet og dødelighet hos barna.

- Det er interessant at barn kan arve morens tarmflora, men koblingen mellom tarmflora og sukkersammensetning i brystmelken er neppe hele forklaringen, sier Marius Trøseid, som er førsteamanuensis og overlege ved Seksjon for klinisk immunologi og infeksjonssykdommer ved Oslo universitetssykehus. Han forteller at hans forskningsgruppe i 2015 publiserte en studie der det ble vist at pasienter med hivinfeksjon hadde lavere bakteriemangfold enn friske, og at dette hadde sammenheng med CD4-nivået i plasma (2).

- I studien fra Haiti var det en numerisk forskjell mellom mødregruppene når det gjaldt forløsningsmetode. Flere hivpositive mødre ble forløst med keisersnitt, noe som er assosiert med økt forekomst av hudbakterier og redusert diversitet i tarmfloraen. De hivpositive mødrene hadde dessuten høyere kroppsmasseindeks. Tarmfloraen fra mødrene ble ikke undersøkt, noe som gjør det vanskelig å tolke hvilke endringer i barnas flora som er nedarvet og hva som skyldes spedbarnsfaktorer, spesielt antiretroviral profylakse til nyfødte og når prøvene fra dem er tatt. Alle disse faktorene vil påvirke tarmfloraen - kanskje mer enn sukkersammensetningen i morsmelken, mener Trøseid.

\section{Ruth Halsne \\ Tidsskriftet \\ Litteratur \\ 1. Bender JM, Li F, Martelly S et al. Maternal HIV infection influences the microbiome of HIV-unin- fected infants. Sci Transl Med 2016; 8: 349ra100. \\ 2. Nowak P. Troseid M, Avershina E et al. Gut micro- biota diversity predicts immune status in HIV-1 infection. AIDS 2015; 29: 2409-18.}

\section{Mekanisme bak ulik atferd hos hanner og hunner}

\author{
Internevroner i frontallappen reduserer angst hos hannmus, men øker \\ interessen for hanner hos hunnmus.
}

Emosjonelle lidelser som autismespekterlidelser er mye hyppigere hos menn enn hos kvinner, mens angstlidelser er vanligere hos kvinner. I en ny studie av mus har man funnet en mulig årsaksmekanisme bak disse forskjellene (1).

Kortikotropinfrigjørende hormon, som er første ledd i hypothalamus-hypofyse-binyrebark-aksen, og oksytocin syntetiseres i hypothalamus, og mer hos hunnmus enn hos hannmus. Oksytocinresponsive internevroner i prefrontallappen utløste ulik atferd hos hannmus og hunnmus. Hannene utskilte et bindeprotein som hemmet virkningen av kortikotropinfrigjørende hormon, og stressberedskap og angst ble dermed redusert. Hunnene fikk ingen angstdempning, men i østrusfase økte tendensen til sosialt samvær med hanner.

Studien ble gjort med genetisk manipulerte mus, der lysimpulser i fiberoptiske kabler kunne initiere aksjonspotensialer $\mathrm{i}$ internevronene både in vivo og $\mathrm{i}$ hjerneskiver. Det var forskjeller i hormonnivå - ikke i nervekoblinger - som førte til ulik atferd hos hannmus og hunnmus.
- Det er rimelig å anta at disse mekanismene for virkningen av kortikotropinfrigjørende hormon og oksytocin i hjernebarken i mus også gjelder mennesker, sier Per Brodal, som er professor emeritus ved Institutt for medisinske basalfag, Universitetet i Oslo. - Men dette er bare én av mange faktorer som påvirker sosial atferd, stemningsleie og seksualitet. Det er all grunn til å tro at forholdene er mer komplekse hos mennesker enn hos mus, sier han.

- Det er ikke mangel på rapporterte forskjeller mellom kvinners og menns hjerner, sier Brodal, som mener at forklaringsverdien for eventuelle kognitive og emosjonelle kjønnsforskjeller er usikker. Dette skyldes blant annet at påviste gjennomsnittlige strukturelle kjønnsforskjeller er langt mindre enn individuelle forskjeller innen hvert kjønn.

Haakon B. Benestad

Universitetet i Oslo

Litteratur

1. Li K, Nakajima M, Ibañez-Tallon I et al. A Cortical Circuit for Sexually Dimorphic Oxytocin-Dependent Anxiety Behaviors. Cell 2016; 167: 60-72.e11.

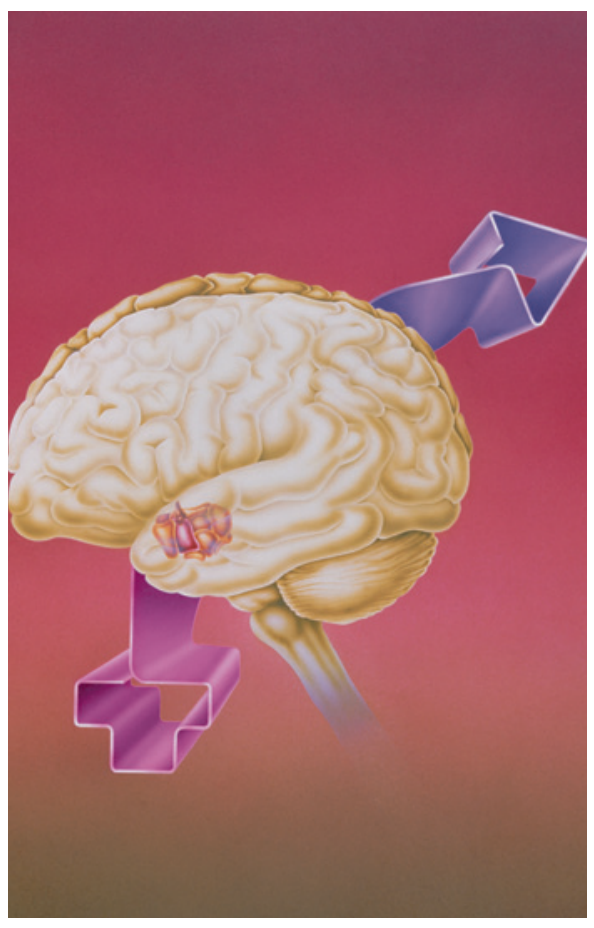

Illustrasjon: Science Photo Library 